\title{
ANALISIS KEMAMPUAN LITERASI SAINS DAN KETERAMPILAN BERPIKIR KRITIS SISWA TERHADAP COVID-19 BERDASARKAN MATERI YANG RELEVAN DALAM PEMBELAJARAN BIOLOGI
}

\author{
Rhavy Ferdyan ${ }^{1)}$, Fitri Arsih ${ }^{2)}$ \\ ${ }^{1,2}$ Jurusan Pendidikan Biologi, Universitas Negeri Padang \\ Email ${ }^{1)}$ fitribio@fmipa.unp.ac.id
}

\begin{abstract}
ABSTRAK: Pendidikan sangat berperan penting dalam memfasilitasi siswa dalam memahami konsep dari peristiwa yang belakangan muncul seperti pandemi COVID-19. Peran pendidikan secara penuh adalah dalam menuntun siswa untuk mendapatkan informasi mengenai COVID-19 salah satunya melalui pembelajaran biologi yang memiliki materi relevan dengan COVID-19. Ketersediaan informasi mengenai COVID-19 dan cara menyikapinya ditentukan oleh kemampuan literasi sains dan keterampilan berpikir kritis siswa. Tujuan penelitian ini adalah untuk melihat tingkat kemampuan literasi sains dan keterampilan berpikir kritis siwa mengenai COVID-19. Penelitian ini merupakan penelitian deskriptif dengan pendekatan kualitatif yang dilakukan di SMAN 16 Padang. Hasil peneltian menunjukkan kemampuan literasi sains siswa terhadap COVID-19 berdasarkan materi biologi yang relevan adalah 57,4 dengan kriteria sedang. Sedangkan tingkat keterampilan berpikir kritis siswa terhadap COVID-19 adalah 60.8\% dengan kriteria rendah. Hal ini disebabkan oleh kurangnya materi pembelajaran yang mengarahkan dan melatih siswa untuk meningkatkan kemampuan literasi sains dan keterampilan berpikir kritis, karena kedua kemampuan tersebut sangat dibutuhkan dalam menjaga keselamatan diri menghadapi pandemi. Sangat diperlukan sebuah rancangan untuk mengembangkan materi pembelajaran biologi untuk meningkatkan kedua kemampuan tersebut.
\end{abstract}

Kata Kunci: COVID-19, Keterampilan Berpikir Kritis, Literasi Sains, Materi biologi

ABSTRACT: Education is a very important role in facilitating students in understanding the concept of recent events such as the COVID-19 pandemic. The full role of education is in guiding students to get information about COVID-19, one of which is through learning biology that has material relevant to COVID-19. the availability of information about COVID-19 and how to respond to it is determined by the scientific literacy and critical thinking skills of students. The purpose of this study was to see the level of scientific literacy and critical thinking skills about COVID-19. This research is a descriptive study with a qualitative approach which was conducted at SMAN 16 Padang. The results of the study showed that students' scientific literacy skills against COVID-19 based on relevant biological materials were 57.4 with moderate criteria. While the level of critical thinking skills against COVID-19 is $60.8 \%$ with low criteria. This is due to the lack of learning that directs and trains students to improve their scientific literacy and critical thinking skills, because these two abilities are very much needed in maintaining personal safety in the face of a pandemic. It is very 
necessary to have a design to develop biology learning materials to improve these two abilities.

Keywords: COVID-19, Critical thinking skill, Science Literacy, Biology material

\section{PENDAHULUAN}

Corona Virus Disease 2019 (COVID-19) ditetapkan sebagai pandemi global oleh World Health Organization (WHO) sejak akhir Februari 2020 (Widyaningrum, 2020). Sudah dapat dilihat saat ini bahwa penderita dari COVID-19 ini sudah dari berbagai kalangan dan rentang umur, termasuk usia remaja. Fakta menunjukkan bahwa generasi milineal yang berusia 15-25 tahun merupakan penderita yang paling banyak terinfeksi bahkan persentasenya terus meningkat dari 4,5 persen menjadi 15 persen (Widyaningrum, 2020). Tingkat kecemasan remaja yang terjadi dalam pandemi COVID-19 berada pada kategori tinggi yaitu 54\% (Fitria \& Ifdil, 2020). Hal ini kemungkinan besar disebabkan oleh informasi yang terkait dengan pandemi COVID-19 sangat kurang diperoleh (Purwanto et al., 2020). Proses perjalanan penyakit ini masih belum banyak diketahui, namun diduga tidak berbeda jauh dengan perjalanan penyakit dari virus pernafasan lainnya yang sudah diketahui (Susilo, 2020).

Pada dasarnya, informasi terkait COVID-19 sudah banyak tersebar sejak pandemi melanda. Remaja sebenarnya dapat memperoleh informasi tantang COVID-19 dari media sosial seperti WhatsApp, Facebook, Twitter, dan Instagram. Akan tetapi, informasi yang tersedia belum dijamin kebenarannya. Hingga tanggal 23 Maret 2020, Kementerian Komunikasi dan Informatika Republik Indonesia telah mencatat sebanyak 305 kontaks hoaks dan disinformasi mengenai COVID-19 yang tersebar di media sosial, website, dan platform pesan instan (Kominfo, 2020). Sebenarnya, saat ini yang paling utama adalah peran pendidikan dalam mengarahkan remaja sebagai siswa di sekolah untuk memiliki pengetahuan yang baik mengenai COVID-19. Pendidikan sangat berperan penting dalam memfasilitasi siswa dalam memahami konsep dari peristiwa yang belakangan muncul seperti pandemi ini. Peran pendidikan yang secara penuh dalam menuntun siswa untuk mendapatkan informasi mengenai COVID-19. Hal ini sangat penting dikarekanakan bidang pendidikan menjadi transmisi pengetahuan. Pengetahuan yang spesifik, valid, dan tepat sasaran yang diberikan pada masyarakat khususnya remaja dapat meningkatkan perilaku usaha pencegahan masyarakat terhadap infeksi COVID-19 sangat perlu dilakukan (Syakurah \& Moudy, 2020). Menurut L. Green, dipengaruhi dan ditentukan oleh tiga faktor yaitu faktor predisposisi (predisposing factor), faktor pemungkin (enabling factor), dan faktor pendorong/penguat (reinforcing factor) (Notoatmodjo,2014). Faktor pendorong atau penguat merupakan faktor yang ditentukan oleh pengetahuan seseorang mengenai infeksi COVID-19. Secara teoretis, bahwa perilaku dapat tercipta karena adanya pengetahuan yang menunjang akan suatu hal. Sehingga sebelum 
muncul perilaku, masyarakat harus mengetahui esensidari manfaat melaksanakan suatu tindakan (Ganing, Salim, \& Muslimin, 2020). Salah satu mata pelajaran yang sangat berperan penting dan berpotensi dalam menyuguhi pengetahuan terkait ini adalah biologi dan ilmu pengetahuan alam.

Pengetahuan yang diperoleh siswa melalui proses pembelajaran biologi dan ilmu pengetahuan alam yang materinya relevan dengan COVID-19 nantinya akan menentukan sikap siswa dalam menyikapi pandemi. Cara menyikapi tersebut dapat dilihat pada kedisiplinan siswa dalam melakukan upaya pencegahan melalui penerapan protokol kesehatan. Saat ini, kecemasan remaja akan COVID-19 tersebut tidak sesuai dengan kesadaran mereka dalam melaksanakan protokol kesehatan secara disiplin. Saat ini masih banyak remaja yang tidak disiplin dalam mencuci tangan dengan sabun, tidak menggunakan masker dengan benar, maupun yang masih cenderung berkerumun.

Penelitian

terdahulu menyebutkan bahwa semakin tinggi pengetahuan remaja dan dukungan terhadap remaja akan meningkatkan kesiapsiagaan dalam menghadapi COVID-19. Setiap individu perlu siapsiaga dalam menghadapi pandemi, saling mendukung dan mengingatkan, karena COVID-19 harus dihadapi bersama (Natalia, Malinti, \& Elon, 2020).

Ketersediaan

informasi COVID-19 yang dibahas sebelumnya, serta upaya pencegahan yang dilakukan, menunjukkan bahwa pentingnya siswa memperoleh informasi yang benar dan ilmiah terkait COVID-19 ini. Maka, kemampuan yang harus dimiliki oleh siswa adalah kemampuan literasi sains. Siswa yang berliterasi sains adalah siswa yang memiliki pengetahuan ilmiah untuk menjelaskan fenomena alam, mendapatkan pengetahuan baru melalui penyelidikan ilmiah, dan menarik kesimpulan berdasarkan bukti ilmiah (OECD, 2015). COVID19 merupakan fenomena alam dan siswa sangat layak dalam memposisikan COVID-19 sebagai pengetahuan baru. Literasi sains ini akan menjadi kompleks jika sumbersumber relevan untuk siswa berliterasi sains tersedia dengan lengkap. Kemudian dari informasi ilmiah yang didapatkan akan menentukan bagaiaman siswa menyikapi COVID-19. Disini sangat diperlukan adalah keterampilan dalam berpikir logis dan reflektif yang difokuskan kepada pengambilan keputusan apa yang harus dipercaya atau apa yang harus dilakukan yang dikenal dengan keterampilan berpikir kritis. Keterampilan ini akan mennentukan siswa akan berpuat apa setelah memperoleh informasi mengenai COVID-19 terkait dengan upaya pencegahan dan menyikapi pandemi COVID-19. Kedua kemampuan diatas sangat dibutuhkan dalam rangka menghadapi pandemi saat ini dan merupakan wujud nyata dalam tuntutan pelaksanaan pembelajaran abad 21. Paradigma pembelajaran abad 21 menekankan kepada kemampuan siswa untuk berpikir kritis, mampu menghubungkan ilmu dengan dunia nyata, menguasai teknologi informasi komunikasi, dan berkolaborasi (Widyanti, 2017). Pandemi COVID19 harus dapat dipahami oleh siswa dengan menghubungkan pengetahuannya dengan kondisi di 
dunia nyata dan mampu menjaga keselamatan diri sendiri dan keluarga.

Oleh karena itu, terkait kecemasan, informasi, perilaku siswa dalam menghadapi pandemi serta pembelajaran abad 21 yang ditentukan oleh kedua hal diatas, perlu dilakukan sebuah analisis kemampuan literasi sains siswa dan keterampilan berpikir kritis siswa tentang COVID-19 untuk memperkuat dan memperjelas fenomena yang menentukan perilaku siswa dalam menyikapi COVID-19. Tujuan dari penelitian ini adalah untuk melihat tingkat kemampuan literasi sains dan keterampilan berpikir kritis siwa mengenai COVID-19. Gambaran kemampuan literasi sains dan keterampilan berpikir kritis siswa terhadap COVID-19 akan menjadi dasar bagi kita untuk menjelaskan upaya pencegahan yang dilakukan oleh siswa saat ini.

\section{METODE PENELITIAN}

Penelitian ini merupakan penelitian deskriptif dengan pendekatan kualitatif yang dilakukan di SMAN 16 Padang. Subjek penelitian adalah seluruh siswa kelas XII SMAN 16 Padang yang berjumlah 90 orang. Siswa kelas XII dipilih sebagai subjek dengan asumsi telah mempelajari materi virus, sistem pernapasan, dan sistem imun dalam pembelajaran biologi. Instrumen penelitian berupa soal tes literasi sains yang mengacu pada indikator PISA dan tes keterampilan berpikir kritis yang mengacu pada indikator Watson Glaser's Critical Thinking Apraisal (WGCTA). Persentase ketercapaian literasi sains ini diinterpretasikan secara deskriptif berdasarkan kriteria hasil tes yang dikemukakan oleh Arikunto (2013) sebagai berikut:

Tabel 1. Kriteria kemampuan Literasi Sains

\begin{tabular}{|c|c|}
\hline Kriteria & Interval \\
\hline Sangat Tinggi & $80-100$ \\
\hline Tinggi & $66-79$ \\
\hline Sedang & $56-65$ \\
\hline Rendah & $40-55$ \\
\hline Sangat Rendah & $30-39$ \\
\hline $\begin{array}{l}\text { Adapun } \mathrm{k} \\
\text { berpikir kritis ya } \\
\text { dilihat pada tabel }\end{array}$ & $\begin{array}{l}\text { keterampilan } \\
\text { unakan dapat }\end{array}$ \\
\hline
\end{tabular}

Tabel 2. Kriteria Keterampilan Berpikir Kritis

\begin{tabular}{cc}
\hline Kriteria & Interval \\
\hline Sangat Tinggi & $81,25<\mathrm{x} \leq 100$ \\
\hline Tinggi & $71,5<\mathrm{x} \leq 81,25$ \\
\hline Sedang & $62,5<\mathrm{x} \leq 71,5$ \\
\hline Rendah & $43,75<\mathrm{x} \leq 62,5$ \\
\hline Sangat Rendah & $0<\mathrm{x} \leq 43,75$ \\
\hline (Setyowati, 2011) &
\end{tabular}

Tes kemampuan literasi sains berupa soal esai berjumlah 30 soal tersebar pada materi virus, sistem pernapasan, dan imun yang menuntut siswa menjawab secara ilmiah menggunakan indikator PISA. Sedangkan tes keterampilan berpikir kritis berjumlah 30 soal tersebar pada materi virus, sistem pernapasan, dan imun dengan 5 indikator yakni; menarik kesimpulan, asumsi, deduksi, menginterpretasi argumen, dan mengevaluasi. Masing-masing tes dikerjakan dalam waktu 60 menit.

\section{HASIL DAN PEMBAHASAN}

Kemampuan Literasi Sains 
Berdasarkan hasil penelitian yang dilakukan rata-rata kemampuan literasi sains siswa terhadap COVID19 berdasarkan materi biologi yang relevan adalah 57,4 dengan kriteria sedang. Analisis secara deskriptif dilakukan untuk melihat kemampuan literasi sains yang dimiliki oleh siswa. Secara keseluruhan persentase dari keterampilan berpikir kritis dapat dilihat pada gambar 1 .

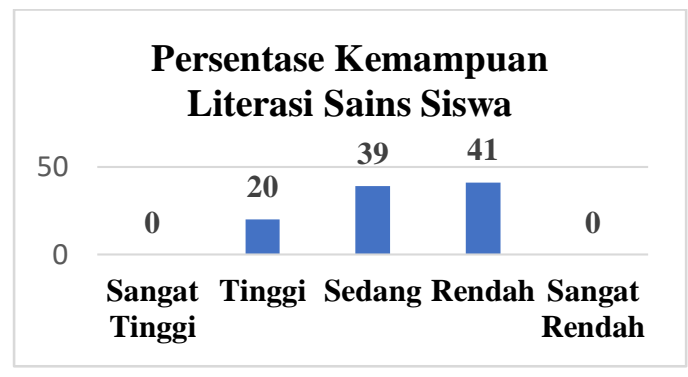

\section{Gambar 1. Persentase Kemampuan} Literasi Sains Siswa

Siswa yang memiliki kemampuan literasi sains dengan kriteria tinggi hanya 20\%. Sedangkan siswa dengan kriteria rendah lebih banyak dengan persentase $41 \%$. Sisanya siswa memiliki kemampuan literasi sains dengan kriteria sedang. Hal yang membuat rata-rata kemampuan literasi sains siswa menjadi kriteria sedang adalah tingginya persentase siswa dengan kemampuan sedang diimbangi dengan kemampuan siswa yang rendah.

\section{Keterampilan berpikir kritis}

Berdasarkan hasil penelitian yang dilakukan diperoleh rata-rata keterampilan berpikir kritis siswa terhadap COVID-19 adalah 60.8 dengan kriteria rendah. Analisis secara deskriptif dilakukan untuk melihat kriteria keterampilan berpikir kritis terhadap COVID-19 yang dimiliki oleh siswa. Siswa yang memiliki keterampilan berpikir kritis dengan kriteria tinggi adalah 18,9\%. Sedangkan siswa dengan kriteria rendah lebih banyak dengan persentase $58,5 \%$. Secara keseluruhan persentase dari keterampilan berpikir kritis dapat dilihat pada gambar 2.

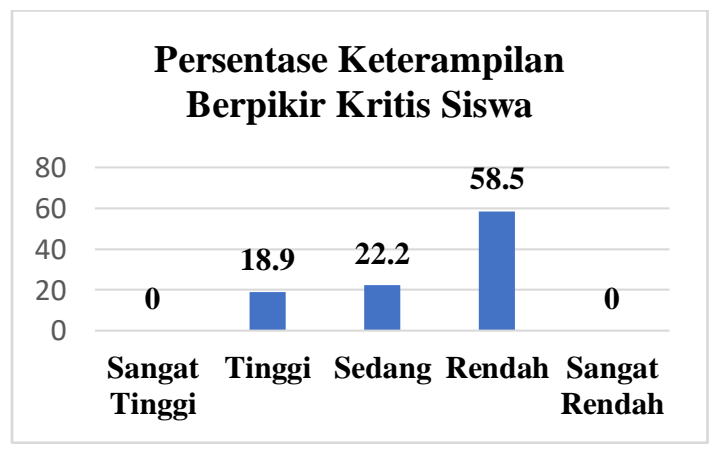

Gambar 2. Persentase

Keterampilan Berpikir Kritis Siswa

Selanjutnya, diperoleh rata-rata lima indikator dari keterampilan berpikir kritis dapat dilihat pada tabel berikut:

Tabel 1. Rata-rata skor keterampulan berpikir kritis

\begin{tabular}{|c|c|c|c|}
\hline Indikator & $\begin{array}{l}\text { Rata- } \\
\text { Rata }\end{array}$ & Kriteria & $\begin{array}{c}\text { Standar } \\
\text { Deviasi }\end{array}$ \\
\hline $\begin{array}{l}\text { Penarikan } \\
\text { Kesimpulan }\end{array}$ & 41,9 & $\begin{array}{l}\text { Sangat } \\
\text { Rendah }\end{array}$ & 10,9 \\
\hline Asumsi & 65,4 & Sedang & 18,3 \\
\hline Deduksi & 65,1 & Sedang & 10,6 \\
\hline $\begin{array}{l}\text { Menafsirkan } \\
\text { Informasi }\end{array}$ & 71,5 & Sedang & 13,5 \\
\hline $\begin{array}{l}\text { Menganalisis } \\
\text { Argumen }\end{array}$ & 60,4 & Rendah & 13,2 \\
\hline
\end{tabular}

Berdasarkan analisis deskriptif pada lima indikator berpikir kritis, diperoleh bahwa kemampuan penarikan kesimpulan memiliki kriteria sangat rendah dengan ratarata $41,9 \quad(\mathrm{SD}=10,9) \quad$ sedangkan kemampuan menganalisis argumen memiliki kriteria rendah dengan rata- 
rata $60,4 \quad(\mathrm{SD}=13,2)$. Indikator asumsi, deduksi, dan menafsirkan informasi memiliki kriteria sedang.

\section{Penarikan Kesimpulan}

Penarikan kesimpulan adalah indikator keterampilan berpikir kritis yang harus dimiliki oleh siswa untuk mampu membedakan antara derajat kebenaran atau kesalahan dari suatu kesimpulan yang diambil berdasarkan pernyataan yang diberikan. Siswa diminta untuk menentukan pilihan dari beberapa alternatif pilihan jawaban berdasarkan pernyataan antara lain; jawaban salah, mungkin salah, butuh informasi tambahan, mungkin benar, dan benar.

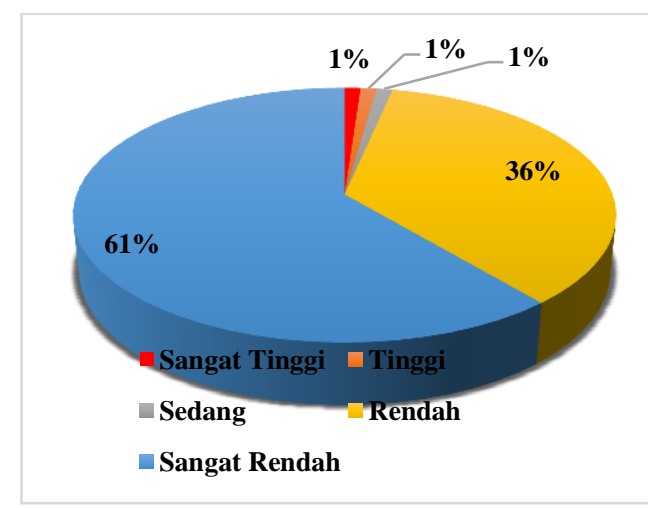

\section{Gambar 3. Persentase Kemampuan Penarikan Kesimpulan}

Berdasarkan hasil penelitian, rata-rata kemampuan penarikan kesimpulan siswa adalah 41,9 dengan kriteria sangat rendah. Rata-rata skor yang diperoleh memperlihatkan hanya $1 \%$ siswa yang memiliki kemampuan penarikan kesimpulan dengaan kriteria sangat tinggi, sedangkan $61 \%$ siswa memiliki kemampuan penarikan kesimpulan dengan kriteria sangat rendah.

\section{Asumsi}

Memberikan asumsi merupakan indikator keterampilan berpikir kritis yang harus dilimiliki oleh siswa dengan menyadari dugaan atau prasangka dari pernyataan atau premis yang diberikan. Indikator memberikan asumsi mengarahkan siswa untuk memilih dua jawaban "ya" atau "tidak. Siswa memilih jawaban "ya" jika asumsi dapat diambil untuk diberikan dalam pernyataan dan logis untuk dibenarkan. Sedangkan memilih "tidak" jika asumsi tidak dapat diambil untuk diberikan dalam pernyataan atau tidak logis untuk dibenarkan

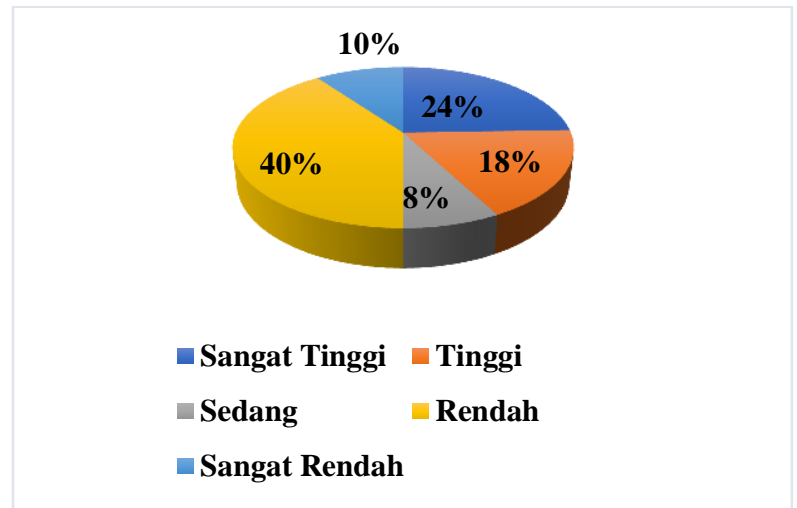

\section{Gambar 4. Persentase Kemampuan Memberikan Asumsi}

Berdasarkan hasil penelitian, rata-rata kemampuan memberikan asumsi siswa adalah 65,9 dengan kriteria sedang. Rata-rata skor yang diperoleh memperlihatkan $24 \%$ siswa yang memiliki kemampuan memberikan asumsi dengan kriteria sangat tinggi, sedangkan $40 \%$ siswa memiliki kemampuan memberikan asumsi dengan kriteria rendah. Indikator memberikan asumsi dan dua indikator berikutnya (deduksi dan menafsirkan informasi) adalah indikator-indikator yang memiliki 
kriteria sedang dalam penelitian ini yang berbeda dengan dua indikator lainnya yang menunjukkan kriteria sangat rendah dan rendah. Dari data yang diperoleh persentase siswa yang memiliki kriteria sangat tinggi, tinggi, dan sedang akan muncul lebih banyak pada tiga indikator ini. Namun, walaupun seperti itu data untuk siswa dengan kriteria rendah dan sangat rendah juga tidak berbeda jauh dengan siswa dengan kriteria tinggi.

\section{Deduksi}

Deduksi merupakan kemampuan memutuskan apakah kesimpulan tertentu harus mengikuti data dari pernyataan atau premis yang telah diberi. Siswa diarakan memilih "ya" jika kesimpulan yang diberikan sesuai dan mengikuti pernyataan yang disajikan. Siswa akan pilih "tidak" jika kesimpulan yang diberikan tidak sesuai atau tidak mengikuti pernyataan yang disajikan.

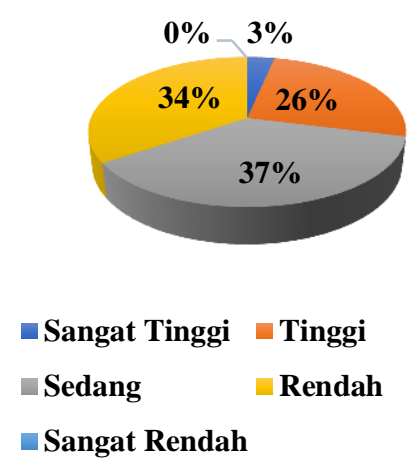

Gambar 5. Persentase Kemampuan Deduksi

Hasil analisis menunjukkan rata-rata kemampuan deduksi siswa adalah 65,1 dengan kriteria sedang. Rata-rata skor yang diperoleh dari hasil penelitian memperlihatkan hanya 3\% siswa yang memiliki kemampuan deduksi dengan kriteria sangat tinggi, sedangkan $34 \%$ siswa memiliki kemampuan deduksi dengan kriteria rendah. Persentase siswa yang paling tinggi adalah $37 \%$ untuk kriteria sedang.

\section{Menafsirkan Informasi}

Menafsirkan informasi menjadi indikator keterampilan berpikir kritis selanjutnya dengan tujuan untuk mengukur bukti-bukti dan menentukan apakah generalisasi atau kesimpulan berdasar pada data yang telah diberikan pada pernyataan atau premis adalah benar. Siswa menentukan pilihan jawaban ya atau tidak. Siswa akan memiilih "ya" jika kesimpulan tersebut selalu sesuai pernyataan yang disajikan. Sedangkan akan memilih "tidak: jika kesimpulan tersebut tidak sesuai pernyataan yang disajikan.

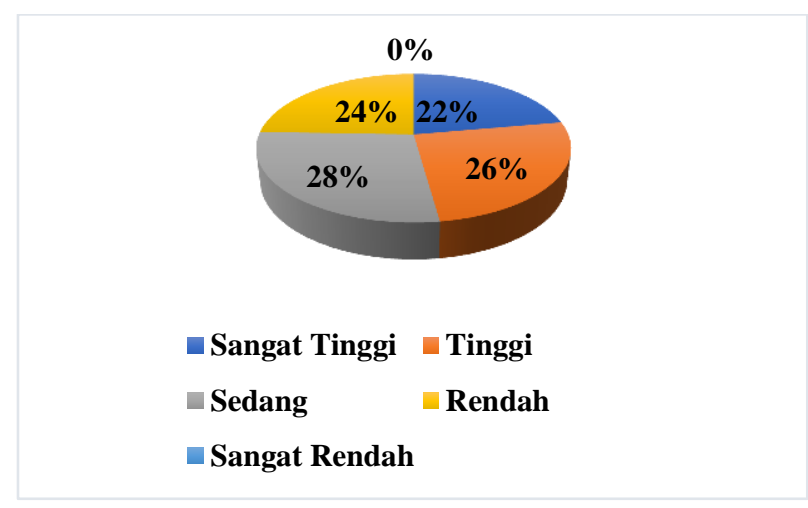

\section{Gambar 6. Persentase Kemampuan Menafsirkan Informasi}

Hasil analisis menunjukkan rata-rata kemampuan menafsirkan informasi siswa adalah 71,5 dengan kriteria sedang. Rata-rata skor yang diperoleh memperlihatkan $22 \%$ siswa yang memiliki kemampuan menafsirkan informasi dengan kriteria sangat tinggi, sedangkan $24 \%$ siswa memiliki kemampuan menafsirkan informasi dengan kriteria rendah. 
Persentase paling tinggi adalah $28 \%$ untuk kriteria sedang.

\section{Menganalisis Argumen}

Indikator menganalisis argumen adalah indikator yang meminta siswa untuk mampu melahirkan sebuah argument atau pendapat terhadap suatu hal yang disajikan dalam pernyataan. Siswa diminta untuk memilih apakah argument tersebut lemah atau kuat. Pilihan argument kuat akan dipilih jika argumen yang diberikan pada jawaban penting dan berkaitan langsung dengan pertanyaan. Sedangkan pilihan argument lemah dipilih jika argumen yang diberikan pada jawaban tidak penting atau tidak berkaitan langsung dengan pertanyaan.

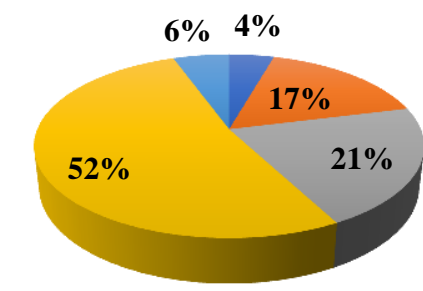

$$
\begin{aligned}
& \text { Sangat Tinggi } \quad \text { Tinggi } \\
& \square \text { Sedang } \quad \text { Rendah } \\
& \text { } \text { Sangat Rendah }
\end{aligned}
$$

\section{Gambar 7. Persentase Kemampuan Menganalisis Argumen}

Berdasarkan hasil penelitian, rata-rata kemampuan menganalisis argumen siswa adalah 60,4 dengan kriteria rendah. Rata-rata skor yang diperoleh memperlihatkan hanya $4 \%$ siswa yang memiliki kemampuan menganalisis argumen dengan kriteria sangat tinggi, sedangkan $52 \%$ siswa memiliki kemampuan menganalisis argumen dengan kriteria rendah.

\section{Pembahasan}

Hasil penelitian menunjukkan bahwa rata-rata keterampilan berpikir kritis siswa terhadap COVID-19 berdasarkan materi pembelajaran biologi yang relevan diperoleh 57,4 dengan kriteria sedang, sedangkan persentase keterampilan berpikir kritis siswa yakni $60.8 \%$ dengan kriteria rendah.

Kemampuan literasi sains siswa yang berkriteria sedang pada dasarnya masih menunjukkan belum adanya kemampuan siswa yang tinggi untuk berliterasi mengenai COVID-19. Kriteria sedang yang diperoleh oleh siswa dalam penelitian ini bisa saja hanya berupa dampak tersedianya informasi COVID-19 yang banyak di media sosial hanya saja tidak terorganisasi. Siswa amat penting mempunyai kesadaran akan literasi sains untuk mengatasi pandemi COVID-19. Literasi sains menuntut seseorang untuk memiliki pengetahuan dalam memerikan (describe), menjelaskan, dan memprediksi fenomena alam salah satunya adalah pendemi COVID-19 (Wibowo, 2021) (Mulbar \& Bahri, 2021).

Keterampilan berpikir kritis merupakan hal yang sangat dibutuhan dalam pembelajaran abad 21 dan menjadi kebutuhan yang diterima secara luas (Hitchcock, 2017). Rendahnya keterampilan berpikir kritis siswa sangat berdampak nantinya kepada tuntutan pembelajaran abad 21. Apalagi dalam menghadapi pandemi COVID-19 saat ini, keterampilan dalam menganalisis permasalahan dan memutuskan Tindakan sangat diperlukan. Hal ini sangat menentukan langkah yang dilakukan seseorang dalam menjaga 
diri dari penularan penyakit berbahaya COVID-19 melalui analisis informasi dan memutuskan suatu tindakan. Berpikir kritis menjadi sangat penting dalam menghadapi kesulitan terhadap ancaman pandemi COVID-19 demi keselamatan diri (Sidabutar \& Hutapea, 2020). Oleh karena itu, sangat penting sekali peran dari pendidikan untuk meningkatkan keterampilan ini salah satunya melalui pembelajaran biologi yang dilakukan di sekolah.

Analisis data yang dilakukan setelah melakukan tes pada materi biologi yang relevan dengan pengetahuan siswa akan COVID-19 menunjukkan dua indikator berpikir kritis dengan kriteria sangat rendah dan rendah; antara lain indikator penarikan kesimpulan dan menganalisis argumen. Pada indikator pertama, yaitu penarikan kesimpulan menunjukkan kriteria sangat rendah dimana $61 \%$ siswa memiliki kriteria sangat rendah dan $36 \%$ siswa memiliki kriteria rendah. Sangat sedikit sekali siswa menjawab dengan tepat untuk menyimpulkan suatu permasalahan, siswa terlihat belum mampu menerapkan keterampilan dalam mengidentifikasi dan mencari bahan yang diperlukan agar dapat menarik kesimpulan, setelah itu mempertimbangkannya. Sedangkan indikator kelima, rata-rata kemampuan menganalisis argumen siswa adalah 60,4 dengan kriteria rendah, masih terdapat $52 \%$ siswa memiliki kemampuan menganalisis argumen dengan kriteria rendah. Banyak terlihat bahwa siswa tidak bisa mempertimbangkan apakah pernyataan yang dianalisis untuk menarik kesimpulan apakah valid atau tidak (Danaryanti \& Lestari, 2017).

Tiga indikator berpikir kritis lainnya menunjukkan kriteria sedang. Indikator kedua, kemampuan memberikan asumsi adalah 65,9 dengan kriteria sedang. Masih ada $40 \%$ siswa memiliki kemampuan memberikan asumsi dengan kriteria rendah. Indikator ketiga, kemampuan deduksi siswa adalah 65,1 dengan kriteria sedang. Masih ada $34 \%$ siswa memiliki kemampuan deduksi dengan kriteria rendah. Indikator keempat, kemampuan menafsirkan informasi siswa adalah 71,5 dengan kriteria sedang. Ada $24 \%$ siswa memiliki kemampuan menafsirkan informasi dengan kriteria rendah. Hal ini menandakan masih banyak siswa yang belum mampu untuk memberikan asumsi, deduksi, dan menafsirkan informasi yang tepat terhadap suatu pernyataan yang diberikan (Danaryanti \& Lestari, 2017) (Faradillah \& Humaira, 2021).

Rendahnya kemampuan literasi sains dan keterampilan berpikir kritis siswa pada dasarnya disebabkan oleh beberapa faktor. Adapun faktornya adalah kurangnya materi pembelajaran yang menyediakan wadah bagi siswa untuk berliterasi yang mendorong siswa untuk berpikir kritis dan selalu melatih keterampilan berpikir kritis dalam pembelajaran. Selama masa pandemi COVID-19 yang mengubah sistem pembelajaran tatap muka menjadi online, materi yang diperoleh siswa dalam pembelajaran biologi kurang dari $60 \%$ mencapai keberhasilan dan belum membangun literasi dan berpikir kritis dalam kegiatan 
preventif (Ferdyan, Lufri, \& Zulyusri, 2020), padahal mata pelajaran biologi sebenarnya dapat menjadi media edukasi bagi siswa untuk mencegah penularan COVID-19 jika pembelajaran maksimal dengan disediakannya bahan yang lengkap untuk menunjang pembelajaran. Kemudian bahan-bahan yang digunakan guru biologi pada saat ini belum mengarahkan siswa untuk berpikir kritis mengenai COVID-19. Ada beberapa pengembangan sebelumnya sudah banyak melakukan pengembangan terhadap materi pembelajaran biologi (Weng, Otanga, Christianto, \& Chu, 2020) (Supriyatin, Nailul, Ichsan, Rahman, \& Gomes, 2020), seperti pengembangan suplemen materi virus untuk penguatan kognitif siswa SMA dengan menyediakan media animasi (Puspitasari, Praherdiono, \& Adi, 2020), suplemen materi sistem pernafasan untuk meningkatkan pemahaman dan sikap siswa terhadap rokok (Elisa, 2019). Penelitianpenelitian tersebut belum mengarahkan siswa untuk meningkatkan literasi sains dan berpikir kritis dengan mengintegrasikan pengetahuan COVID-19 didalamnya.

Keterampilan berpikir kritis sangat memerlukan dukungan dari kemampuan kognisi yang baik oleh setiap siswa (Kurniawan, Saputra, Aiman, Alfaiz, \& Sari, 2020). Perlu materi-materi pembelajaran yang mengintegrasikan kehidupan nyata untuk menganalisis permasalahanny seperti COVID-19 ini dan sangat besar manfaatnya bagi siswa dalam menghadapi pandemi. Selain itu, ada beberapa strategi pembelajaran yang digunakan oleh pendidikan untuk mengarahkan dan melatih keterampilan berpikir kritis siswa anara lain dengan problem based learning (PBL) (Martyn, Terwijn, Kek, \& Huijser, 2014) (Arsih, Zubaidah, Suwono, \& Gofur, 2020), project based learning ( $\mathrm{PjBL})$ (Anazifa \& Djukri, 2017), discovery learning (Yerimadesi et al., 2019), dan blended learning (Jou, Lin, \& $\mathrm{Wu}, \quad 2016)$ Implementasinya menunjukkan peningkatan kemampuan siswa untuk berpikir kritis. Dampak positif yang diperoleh adalah sebagian besar siswa cepat merespon pesan yang diberikan guru dengan secara cepat mengidentifikasi masalah yang disampaikan guru serta mampu memanfaatkan informasi yang diperoleh dari beberapa sumber belajar.

Oleh karena itu, pelaksanaan strategi pembelajaran yang tepat dan efektif untuk meningkatkan literasi sains dan keterampilan berpikir kritis berawal dari pengembangan materi pembelajaran yang disediakan untuk diterapkan dalam beberapa strategi pembelajaran (Sutiani, 2021) (Santoso, Primandiri, Zubaidah, \& Amin, 2021). Solusi yang dapat ditawarkan dalam permasalahan ini adalah perlu dirancang sebuah kumpulan materi pembelajaran yang mengintegrasikan pengetahuan COVID-19 serta mengarahkan dan meotivasi siswa untuk meningkatkan literasi sainsnya dan berpikir kritisnya dalam beberapa materi pembelajaran biologi, sehingga materi pembelajaran dan informasi mengenai COVID-19 diperoleh siswa dengan jelas dan mampu meningkatkan kedua kemampuan tersebut. 


\section{KESIMPULAN}

Kemampuan literasi sains dan keterampilan berpikir kritis sangat diperlukan dalam pembelajaran abad 21 serta dalam rangka menghadapi pandemi COVID-19 yang terjadi saat ini. Hasil penelitian menunjukkan bahwa kemampuan literasi sains siswa berada pada kriteria sedang. Hal ini menandakan belum adanya motivasi dari siswa untuk melakukan literasi sains, yang diperlukan peningkatan untuk menganalisis informasi terkait COVID-19. Sedangkan keterampilan berpikir kritis siswa maish tergolong rendah. Hal ini disebabkan oleh faktor ketidaktersediaan bahan pembelajaran yang mengarahkan siswa untuk meningkatkan keterampilan tersebut yang juga berdampak pada tidak terlaksananya strategi pembelajaran yang meningkatkan keterampilan berpikir kritis. Perlu dirancang sebuah pengembangan materi pembelajaran untuk mengatasi masalah ini.

\section{DAFTAR PUSTAKA}

Anazifa, R. D., \& Djukri, D. (2017). Project-Based Learning and Problem-Based Learning: Are They Effective to Improve Student's Thinking Skills? Jurnal Pendidikan IPA Indonesia, 6(2), 346-355.

Arsih, F., Zubaidah, S., Suwono, H., \& Gofur, A. (2020). Critical thinking skills of prospective biology teachers: A preliminary analysis. AIP Conference Proceedings. AIP Publishing LLC.

Danaryanti, A., \& Lestari, A. T.
(2017). Analisis Kemampuan Berpikir Kritis Dalam Matematika Mengacu Pada Watson-Glaser Critical Thinking Appraisal Pada Siswa Kelas VIII SMP Negeri di Banjarmasin Tengah Tahun Pelajaran 2016/2017. EDU-MAT Jurnal Pendidikan Matematika, 5(2), 115-119.

Elisa, D. (2019). Pengembangan Suplemen Bahan Ajar Berbasis Mini Riset Untuk Meningkatkan Pemahaman Konsep dan Sikap Siswa Berkaitan dengan Rokok. Universitas Negeri Semarang.

Faradillah, A., \& Humaira, T. (2021). Mathematical Critical Thinking Skills Senior High School Student Based on Mathematical Resilience and Domicile. Jurnal Cendekia: Jurnal Pendidikan Matematika, 5(2), 1978-1991.

Ferdyan, R., Lufri, L., \& Zulyusri, Z. (2020). Content Analysis and Implementation of Biology Online Learning Materials in SMA/MA/SMK During The COVID-19 Pandemic. Journal of Biology Education, 9(3), 41348.

Fitria, L., \& Ifdil, I. (2020). Kecemasan remaja pada masa pandemi Covid-19. Urnal EDUCATIO: Jurnal Pendidikan Indonesia, 6(1), 1-4.

Ganing, A., Salim, A., \& Muslimin, I. (2020). Studi Literatur: Pengetahuan sebagai Salah Satu Faktor Utama Pencegahan Penularan COVID-19. Jurnal Kesehatan Manarang, 6(1), 5560.

Hitchcock, D. (2017). Do the fallacies have a place in the teaching of 
reasoning skills or critical thinking? Springer, Cham: Cham.

Jou, M., Lin, Y.-T., \& Wu, D.-W. (2016). Effect of a blended learning environment on student critical thinking and knowledge transformation. Interactive Learning Environments, 24(6), 1131- 1147.

Kominfo. (2020). Laporan Isu HOAX. Jakarta: Kominfo.

Kurniawan, N. A., Saputra, R., Aiman, U., Alfaiz, A., \& Sari, D. K. (2020). Urgensi Pendidikan Berpikir Kritis Era Merdeka Belajar bagi Peserta Didik. Tarbawi: Jurnal Ilmu Pendidikan, 16(1), 104-109.

Martyn, J., Terwijn, R., Kek, M. Y. C. A., \& Huijser, H. (2014). Exploring the relationships between teaching, approaches to learning and critical thinking in a problem-based learning foundation nursing course. Nurse Education Today, 34(5), 829835.

Mulbar, U., \& Bahri, A. (2021). Biology Science Literacy of Junior High School Students in South Sulawesi, Indonesia. Journal of Physics: Conference Series, 1752(1), 120.

Natalia, R. N., Malinti, E., \& Elon, Y. (2020). Kesiapsiagaan Remaja Dalam Menghadapi Wabah Covid-19. NHIHC: NANI HASANUDDIN

INTERNATIONAL HEALTH CONFERENCE.

OECD. (2015). PISA 2015 Draft mathematics framework. New York: Columbia University
Press.

Purwanto, A., Pramono, R., Asbari, M., Hyun, C. C., Wijayanti, L. M., \& Putri, R. S. (2020). Studi Eksploratif Dampak Pandemi COVID-19 Terhadap Proses Pembelajaran Online di Sekolah Dasar. EduPsyCouns: Journal of Education, Psychology and Counseling, 2(1), 1-12.

Puspitasari, D., Praherdiono, H., \& Adi, E. (2020). Pengembangan Suplemen Augmented Reality Animation Pada Buku Mata Pelajaran Biologi Untuk Penguatan Kognitif Siswa SMA. Jurnal Kajian Teknologi Pendidikan, 3(1), 29-39.

Santoso, A. M., Primandiri, P. R., Zubaidah, S., \& Amin, M. (2021). Improving student collaboration and critical thinking skills through ASICC model learning. Ournal of Physics: Conference Series, 1806(1), 121.

Setyowati, A. (2011). Implementasi Pendekatan Konflik Kognitif dalam Pembelajaran Fisika untuk Menumbuhkan Kemampuan Berpikir Kritis Siswa Kelas VIII. Jurnal Pendidikan Fisika Indonesia, 7(1), 89-96.

Sidabutar, H., \& Hutapea, R. H. (2020). Sikap Kritis Manusia di Masa Pandemi Covid-19 Dalam Perspektif Filsafat Pendidikan. Widyadewata: Jurnal Balai Diklat Keagamaan Denpasar, 3(1), 21-31.

Supriyatin, A., Nailul, R., Ichsan, I. Z., Rahman, M. M., \& Gomes, P. W. P. (2020). HOTS Analysis to Develop E-Supplement Book 
Based on Plant Physiology

Research. Universal Journal of Educational Research, 8(12), 8461-8466.

Susilo, A. (2020). Coronavirus Disease 2019: Tinjauan Literatur Terkini. Jurnal Penyakit Dalam Indonesia, 7(1), 45-67.

Sutiani, A. (2021). Implementation of an Inquiry Learning Model with Science Literacy to Improve Student Critical Thinking Skills. International Journal of Instruction, 14(2), 117-138.

Syakurah, R. A., \& Moudy, J. (2020). Pengetahuan terkait usaha pencegahan Coronavirus Disease (COVID-19) di Indonesia. HIGEIA (Journal of Public Health Research and Development), 4(3), 333-346.

Weng, C., Otanga, S., Christianto, S. M., \& Chu, R. J.-C. (2020). Enhancing Students' Biology Learning by Using Augmented Reality as a Learning Supplement. Journal of Educational Computing Research, 58(4), 747-770.

Wibowo, A. (2021). Analisis Literasi
Sains Siswa Sekolah DasarPada Kasus Pandemi Covid-19. Jurnal Educatio, 7(2), 515-519.

Widyaningrum, G. L. (2020). WHO Tetapkan COVID-19 Sebagai Pandemi Global, Apa Maksudnya? Retrieved June 6, 2020, from National Geographic Indonesia website: https://nationalgeographic.grid.id /read/132059249/who-tetapkancovid-19-sebagai-pandemiglobal-apa-maksudnya

Widyanti, T. (2017). Keterampilan Belajar Abad 21 Untuk Melatih Berpikir Kritis Melalui Sistem Pembelajaran Berbasis ICT. Administrasi Pendidikan : Jurnal Ilmiah Mahasiswa Pascasarjana, 5(2), 22-31.

Yerimadesi, Y., Bayharti, B., Azizah, A., Lufri, L., Andromeda, A., \& Guspatni, G. (2019). Effectiveness of acid-base modules based on guided discovery learning for increasing critical thinking skills and learning outcomes of senior high school student. Journal of Physics: Conference Series, 1185(1), 12151. 